Journal of Engineering Sciences. Assiut University. Vol. 35, No. 2, pp. 381-400, January

\title{
INFLUENCE OF STIRRUPS AND CONCRETE STRENGTH ON BEHAVIOUR OF RC BEAMS STRENGTHENED IN SHEAR WITH CFRP_STRIPS
}

\author{
Atif M. Abdel Hafez \\ Civil Eng. Dept., Assiut University
}

(Received Febrary26, 2007 Accepted March 18, 2007)

This paper presents the results of an experimental investigation conducted on rectangular $R C$ beams strengthened externally in shear with CFRP-U strips. The main objective of this research was to evaluate experimentally and analytically the influence of the following parameters on the shear performance of such beams; amount of internal shear reinforcement with and without (stirrups), amount of longitudinal steel, and concrete compressive strength (normal and high strength). Test results indicated that the contribution of CFRP strips to the shear capacity of beams is strongly influenced by the studied parameters. CFRP strips are less effective when beams are heavily reinforced with stirrups. The gain in shear capacity increases as amount of longitudinal steel and/or concrete compressive strength increases. After analyzing the experimental results, the empirical model previously proposed by the author, to predict the contribution of CFRP-U strips, was modified to take the effect of the studied parameters into consideration. The modified model can predict the experimental results with acceptable accuracy, while ACI code guidelines fail to capture the influence of the studied parameters. At the end, recommendations for further work have been given.

KEYWORDS: RC beams, shear strengthening, carbon fiber reinforced polymer CFRP-U strips, steel stirrups.

\section{NOTATION}

$a=$ Shear span of beam, mm,

$A_{f}=$ Cross-sectional area of CFRP strips within spacing $\mathrm{S}_{\mathrm{f}}, \mathrm{mm}^{2}$,

$b \quad=$ Width of beam crosssection (web width), mm. $d=$ Effective depth of beam, $\mathrm{mm}$.

$d_{f}=$ Effective depth of CFRP-U strips, $\mathrm{mm}$.

$E_{f} \quad=$ Modulus of elasticity of CFRP, MPa. 


\begin{tabular}{|c|c|c|}
\hline$f_{c u}$ & $\begin{aligned}= & \text { Cube compressive strength } \\
& \text { of concrete, } \mathrm{MPa} .\end{aligned}$ & $\begin{array}{l}=\text { CFRP effective thickness, } \\
\text { mm. }\end{array}$ \\
\hline$F_{f e}$ & $\begin{aligned}= & \text { Effective stress of CFRP-U } \\
& \text { strips, intersected by shear } \\
& \text { crack, MPa. }\end{aligned}$ & $\begin{aligned}= & \text { Shear contribution of } \\
& \text { CFRP-U strips, to shear } \\
& \text { capacity of beam, } \mathrm{kN} .\end{aligned}$ \\
\hline$f_{f u}$ & $\begin{aligned}= & \text { Ultimate tensile strength of } \\
& \text { CFRP-strips, MPa. } \\
= & \text { Bond length ratio. }\end{aligned}$ & $\begin{aligned} V_{\text {fexp. }}= & \text { Experimental shear } \\
& \text { contribution of CFRP-U } \\
& \text { strips, } \mathrm{kN} .\end{aligned}$ \\
\hline $\begin{array}{l}\text { Le } \\
n\end{array}$ & $\begin{array}{l}=\text { Effective bond length, mm. } \\
=\text { Number of CFRP layers per }\end{array}$ & $\begin{aligned} V_{\text {fpre }}= & \text { Predicted shear contribution } \\
& \text { of CFRP-U-strips, } \mathrm{kN} .\end{aligned}$ \\
\hline & strip. & $=$ Width of CFRP strips, mm. \\
\hline$R$ & $\begin{aligned}= & \text { Ratio of effective to } \\
& \text { ultimate strength of CFRP }\end{aligned}$ & $\begin{aligned}= & \text { Effective strain of CFRP-U } \\
& \text { strips, at failure. }\end{aligned}$ \\
\hline$S_{f}$ & $\begin{aligned} & \text { strips. } \\
= & \text { Central spacing of CFRP-U }\end{aligned}$ & $\begin{array}{l}=\text { Ultimate tensile (rupture) } \\
\text { strain of CFRP strips. }\end{array}$ \\
\hline & $\begin{array}{l}\text { strips, measured along the long. } \\
\text { axis of beam mm. }\end{array}$ & $\begin{aligned}= & \text { Longitudinal reinforcement } \\
& \text { ratio. }\end{aligned}$ \\
\hline$S_{s}$ & $\begin{array}{l}=\text { Spacing between steel } \\
\text { stirrups, mm, }\end{array}$ & $\begin{aligned} \varepsilon_{\text {max. }}= & \text { Maximum tensile strain in } \\
& \text { CFRP-strips measured just } \\
& \text { before failure. }\end{aligned}$ \\
\hline
\end{tabular}

\section{INTRODUCTION}

In recent years, the technique of strengthening or repairing reinforced concrete structures with externally bonded carbon fiber reinforced polymer (CFRP) has been successfully applied and has become popular. Over the past several years, there has been a concerned research effort to explore the strengthening effect of advanced composite materials in the form of thin laminates or fabrics such as carbon fiber reinforced polymer (CFRP) laminates. Strengthening of beams and slabs in flexure are well documented. In contrast, due to the complexity related to shear, the number of researches on shear strengthening is relatively limited [1-13].

Review of research studies carried out on shear strengthening [1-13] revealed that a lot of parameters, which influence the shear resistance mechanism, were not sufficiently documented. Transverse and longitudinal steel reinforcement ratios and concrete strength are examples of such parameters. Therefore, an extensive research is carried out at Assiut University, to study the influence of such parameters on the shear performance of RC beams strengthened in shear with externally bonded CFRP-U strips. The objectives of the research were: 
1. To study experimentally the influence of amount of internal shear reinforcement (with and without steel stirrups), amount of longitudinal steel, and concrete compressive strength (normal and high strength) on the behaviour of reinforced concrete beams strengthened in shear with externally bonded CFRP-U strips.

2. To determine whether or not the existing codes and calculation models are valid and applicable for such beams. Codes and calculation models referred in this study are: ACI code [14] (i.e. Egyptian Code [19]), and author's model [1].

3. To develop, if necessary, new equations or modify the existing ones, for more accurate prediction of contribution of CFRP strips to the shear strength of such beams.

\section{EXPERIMENTAL PROGRAM}

\subsection{Test Specimens:}

In order to achieve the prior objectives, eighteen RC beams were designed and tested. The dimensions of the tested beams were $120 \mathrm{~mm}$ (width) x $300 \mathrm{~mm}$ (depth) x $1940 \mathrm{~mm}$ (span). All beams were designed to fail in shear. The experimental program consisted of three series. Series No. 1 designed to have a concrete compressive strength of $30 \mathrm{MPa}$ (Normal strength concrete); while series No. 2 and 3 designed to have $f_{c u}$ of about $70 \mathrm{MPa}$ (high-strength concrete). Nine beams were not strengthened with CFRP and kept as control specimens, whereas other beams were strengthened in shear spans with CFRP$\mathrm{U}$ strips of $60 \mathrm{~mm}$ width and of $120 \mathrm{~mm}$ spacing (center-to-center). The width and spacing of the CFRP-U strips used in this study were chosen according to the conclusions and recommendations of a previous research carried by the author [1]. Table (1) and Fig. (1) show details of test specimens and the parameters investigated.

\subsection{Materials:}

- Details of mix proportions and compressive strength of concrete for normal and high strength concrete are presented in Table (2). Ordinary Portland cement and local natural sand were used. Graded gravel and crushed basalt with maximum size $20 \mathrm{~mm}$ were used as coarse aggregate for both normal and high strength concrete respectively. To enhance the strength and the workability of high-strength concrete, Silica Fume, and water reducing admixture (Sekament F.F.3) were used.

- Two diameters of high strength deformed bars 22 and $12 \mathrm{~mm}$ of 440 and $470 \mathrm{MPa}$ proof-strength respectively were used for longitudinal 
reinforcement. Mild steel plain bars of $6 \mathrm{~mm}$ diameter and of $340 \mathrm{MPa}$ yield strength were used for stirrups.

Table 1: Specimen details

\begin{tabular}{|c|c|c|c|c|c|c|}
\hline \multirow{3}{*}{$\begin{array}{c}\text { Series } \\
\text { No. }\end{array}$} & \multirow{3}{*}{$\begin{array}{l}\text { Beam } \\
\text { No. }\end{array}$} & \multirow{3}{*}{$\begin{array}{c}f_{c u} \\
(\mathrm{MPa})\end{array}$} & \multirow{3}{*}{$\begin{array}{c}\text { Long. Steel } \\
\rho(\%)\end{array}$} & \multicolumn{3}{|c|}{ Shear strengthening system } \\
\hline & & & & \multirow{2}{*}{$\begin{array}{l}\text { Steel stirups } \\
\text { dia. \& spac. } \\
(\mathrm{mm})\end{array}$} & \multicolumn{2}{|c|}{ CFRP-U strips } \\
\hline & & & & & $\mathbf{W f}_{\mathrm{mm}}$ & $\mathbf{S f}_{\mathrm{mm}}$ \\
\hline \multirow{6}{*}{1} & $\mathrm{BN}-1$ & 33 & 0.0235 & Without & - & - \\
\hline & BNF-1 & 34 & 0.0235 & Without & 60 & 120 \\
\hline & $\mathrm{BN}-2$ & 33 & 0.0235 & $\phi 6 @ 300$ & - & - \\
\hline & BNF-2 & 33 & 0.0235 & ф6@300 & 60 & 120 \\
\hline & $\mathrm{BN}-3$ & 32 & 0.0235 & $\phi 6 @ 150$ & - & - \\
\hline & BNF-3 & 32 & 0.0235 & p6@150 & 60 & 120 \\
\hline \multirow{6}{*}{2} & $\mathrm{BH}-1$ & 74.0 & 0.0235 & Without & $\begin{array}{c}- \\
\end{array}$ & - \\
\hline & BHF-1 & 74.0 & 0.0235 & Without & 60 & 120 \\
\hline & $\mathrm{BH}-2$ & 72.5 & 0.0235 & ф6@300 & - & - \\
\hline & BHF-2 & 72.5 & 0.0235 & ф6@300 & 60 & 120 \\
\hline & $\mathrm{BH}-3$ & 71.0 & 0.0235 & ф6@150 & - & - \\
\hline & BHF-3 & 71.0 & 0.0235 & p6@150 & 60 & 120 \\
\hline \multirow{6}{*}{3} & $\mathrm{BH}-4$ & 75 & 0.0470 & Without & - & - \\
\hline & BHF-4 & 75 & 0.0470 & Without & 60 & 120 \\
\hline & $\mathrm{BH}-5$ & 74 & 0.0470 & $\phi 6 @ 300$ & - & - \\
\hline & BHF-5 & 74 & 0.0470 & p6@300 & 60 & 120 \\
\hline & BH-6 & 72 & 0.0470 & p6@150 & - & - \\
\hline & BHF-6 & 72 & 0.0470 & $\phi 6 @ 150$ & 60 & 120 \\
\hline
\end{tabular}

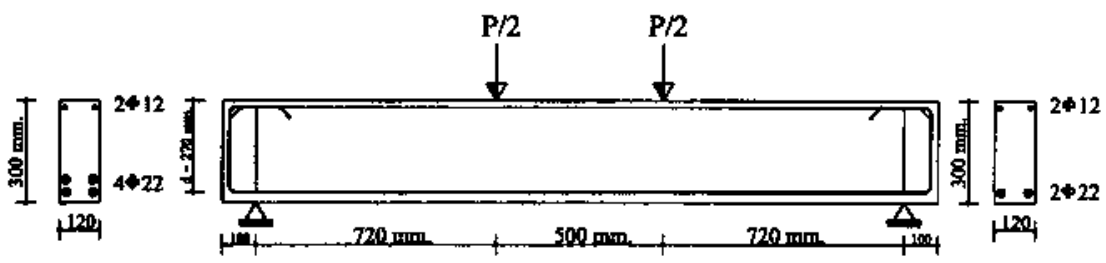

Se. 3

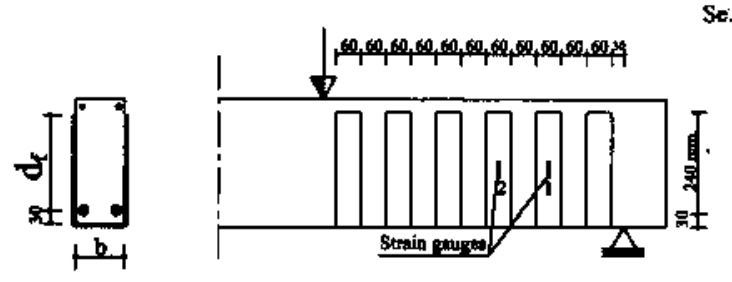

Fig.1: Specimen details. 
- Unidirectional Carbon Fiber Reinforced Polymer (CFRP) of $0.12 \mathrm{~m}$ effective thickness was used for external shear strengthening. According to the supplier the fabrics had an elastic modulus of $231000 \mathrm{MPa}$, tensile strength of $4100 \mathrm{MPa}$ and rupture strain of $1.7 \%$.

- An epoxy mortar, under a commercial name of (Sikadur-41) was applied to all strengthened beams as a substratum primer to the CFRP lamingtes, and an epoxy adhesive (Sikadur-330) was used for bonding the laminates. Properties of these materials have given before [1].

Table 2: concrete mix proportions.

\begin{tabular}{|c|c|c|c|c|c|c|c|}
\hline \multirow[b]{2}{*}{$\begin{array}{c}\mathbf{f}_{\mathrm{cu}} \\
\mathrm{N} / \mathrm{mm}^{2}\end{array}$} & \multirow[b]{2}{*}{$\begin{array}{l}\text { Cement } \\
\left(\mathrm{Kg} / \mathrm{m}^{3}\right)\end{array}$} & \multirow[b]{2}{*}{$\begin{array}{c}\text { Fine } \\
\underset{\left(\mathrm{Kg} / \mathrm{m}^{3}\right)}{\text { aggregate }}\end{array}$} & \multicolumn{2}{|c|}{ Coarse agg. $\left(\mathrm{kg} / \mathrm{m}^{3}\right)$} & \multirow[b]{2}{*}{$\begin{array}{c}\text { Silica } \\
\text { Fume } \\
\left(\mathrm{Kg} / \mathrm{m}^{3}\right)\end{array}$} & \multirow[b]{2}{*}{$\begin{array}{c}\text { Sekament } \\
\left({ }^{\left.\text {lit } / \mathbf{m}^{3}\right)}\right.\end{array}$} & \multirow[b]{2}{*}{$\begin{array}{l}\text { Water } \\
\left(\mathrm{lit} / \mathrm{m}^{3}\right)\end{array}$} \\
\hline & & & $\begin{array}{l}\text { Gravel } \\
20 \mathrm{~mm}\end{array}$ & $\begin{array}{c}\text { Crushed } \\
\text { basalt } \\
(10 \mathrm{~mm})\end{array}$ & & & \\
\hline 30 & 400 & 620 & 1220 & - & - & - & 180 \\
\hline 70 & 500 & 600 & - & 1200 & 100 & 15 & 150 \\
\hline
\end{tabular}

\subsection{Strengthening Technique:}

The surfaces of the beam where the CFRP-U strips should be bonded were roughened and cleaned, and the corners of the beam were rounded in curved shape of $30 \mathrm{~mm}$ diameter. Then an epoxy mortar (Sikadur-41) of about 2.0 $\mathrm{mm}$ thickness was applied to these surfaces as substratum to the CFRP strips, but before that a primer coat (Sikadur-31) was applied to promote the adhesion between the concrete surface and the mortar. After about 24 hours the CFRPU strips were glued using epoxy adhesive (Sikadur-330).

\subsection{Test Procedure:}

All beams were tested simply supported and the load was applied through two symmetrical points of $520 \mathrm{~mm}$ apart as shown in Fig. (1). The load was applied to the beams in increments. At each increment the mid-span deflection and the strains in the middle height of some of the CFRP-U strips were measured. During test, crack initiation and propagation were recorded.

\section{TEST RESULTS AND DISCUSSION}

\subsection{Cracking and Failure Modes:}

Figure (2) shows the failure modes of some beams. Initially, a flexural crack occurred in the zone of pure bending. As the load increased, more flexural cracks developed and a diagonal crack occurred. All control beams failed in shear and the failure was resulted from a critical diagonal tension shear crack. Beams without stirrups failed suddenly, and the failure of these beams become 
more sudden and explosive as the concrete strength increased, while beams with stirrups presented a more ductile response, especially in case of beams with stirrup of $150 \mathrm{~mm}$ spacing.

All strengthened beams failed in shear (diagonal tension) except beams BHF-2 and BHF-3 which failed in flexure before they reached their maximum shear strength capacities. The diagonal tension failure was preceded by CFRPU strips bond failure and/or strips rupture, and the diagonal crack occurred at a higher load than for control beams. It has to be mentioned that failure of these beams become more sudden and explosive as the concrete strength increases especially those with higher ratio of main steel and/or larger stirrup spacing or with no stirrups.

\subsection{Load-Deflection Behaviour:}

Figures (3 and 4) show the relationship between the shear load and mid-span deflection for the test beams. Each successive curve is offset by $2 \mathrm{~mm}$ to facilitate the comparison. The following observations can be made from these figures:

- In the first stage of loading, prior to cracking, the curves of beams of each series are very similar, but after the occurrence of diagonal cracking, the addition of web reinforcement and/or external shear reinforcement (CFRPU strips) has a significant effect on both ultimate load and ductility.

- High strength concrete beams strengthened with CFRP showed a substantially higher shear resistance compared to control beams in comparison with those made of normal strength concrete.

- For specimens with nearly the same compressive strength of concrete, the ultimate load and the stiffness of the beam increased with increasing amount of longitudinal steel.

- The addition of web reinforcement and bonded CFRP-U strips improves the shear response of the specimens by increasing the failure shear load and a higher ductile response.

\subsection{CFRP Strains}

Figures (5 and 6) present the curves of the shear load versus the strains in the CFRP-U strips for all specimens (bigger value of strain No. 1 or 2). All curves presented in these figures show that the CFRP strips did not contribute to the load carrying capacity in the initial stage of loading. Thereafter, the strain started to increase steadily up to failure. In case of beams made with high strength concrete, the strain attained a value of $4550 \mu$ strain, while only 4050 $\mu$ strain in companion beams made with normal strength concrete. This means that the CFRP contribution to the shear resistance is greater in case of high strength concrete beams than normal strength concrete beams. 


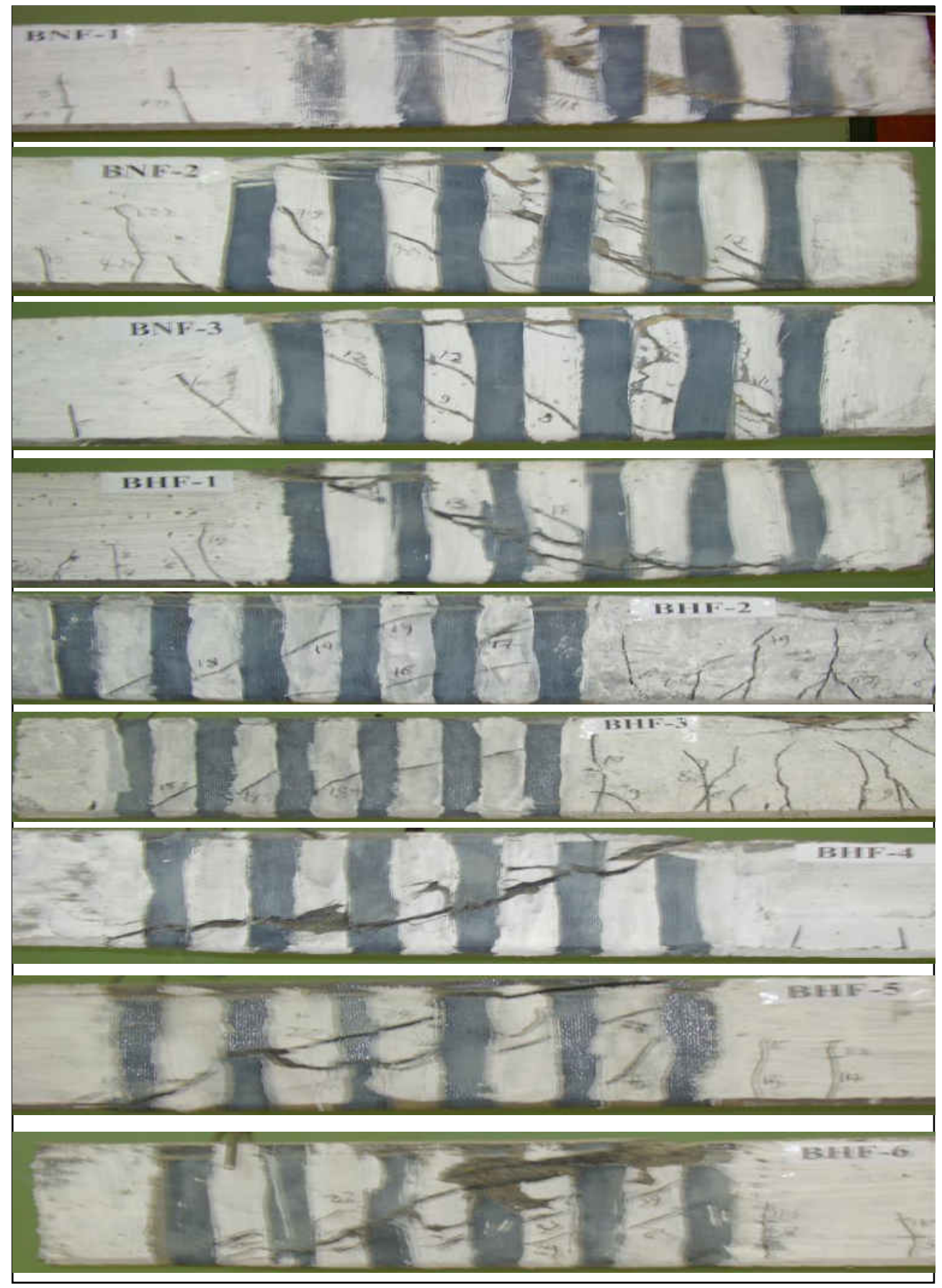

Fig.2: Mode of failure of strengthened beams. 

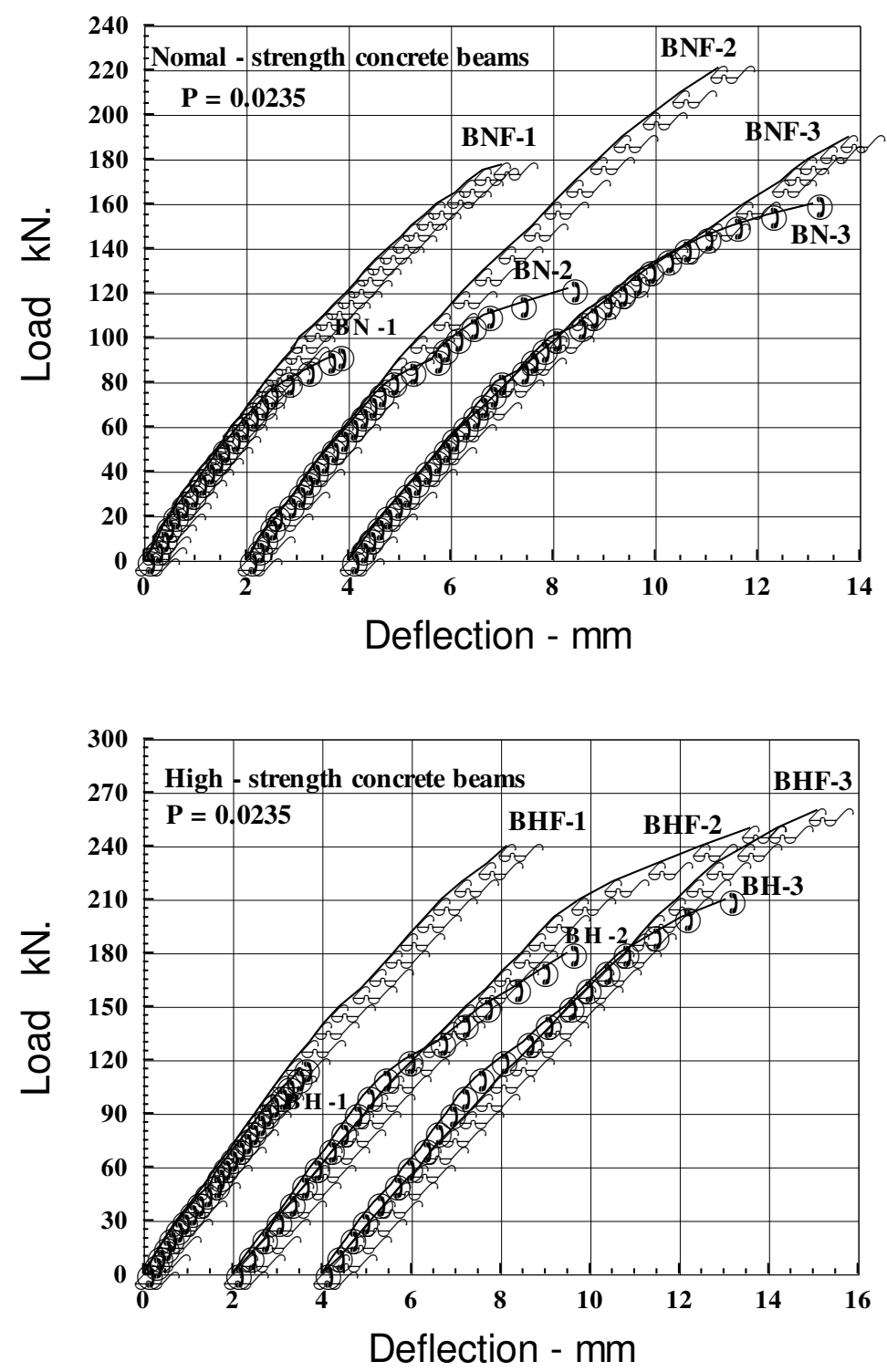

Fig.3: Load-midspan deflection (series 1 and 2).

Comparison of maximum measured strains of beams in series 2 and 3 (Table 3) reveals that the maximum strain recorded were greater for beam of series 3 than those in series 2. For example, the measured strain reached 7640 $\mu$ strain in case of beam BHF-4 in comparison with only $4100 \mu$ strain in case of beam BHF-1. 


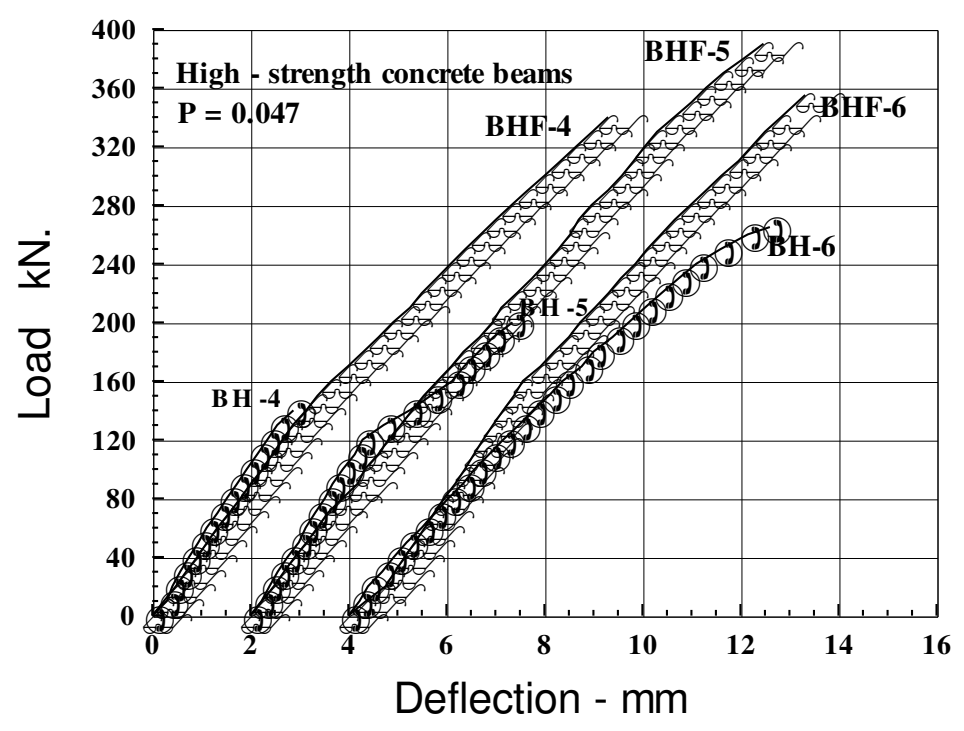

Fig.4: Load-midspan deflection (series 3).

Figure (7) shows that the two fiber strips crossing the shear crack experienced nearly the same level of strain especially near failure. This means that the load carried by the fiber strips crossing the crack is uniformly distributed between these strips. This observation is in agreement with that reported before by Deniaud et al. [12].

\subsection{Shear Strengthening Influence on Beam Capacity:}

Test results showed that the contribution of CFRP-strips to the shear capacity of RC beams depends not only on the dimensions and spacing of U-strips as mentioned in previous research [1], but also on the amount of both transverse (stirrups) and longitudinal steel, and concrete strength as follows:

\section{Influence of amount of stirrups:}

Results in Table (3) indicates the existence of a strong interaction between both amount of internal shear reinforcement (stirrups) and external shear strengthening (CFRP-U strips), in term of the gain in shear capacity. CFRP-U strips are less effective when beams are heavily reinforced internally. For example in case of normal strength concrete beams strengthened with the same amount of CFRP-U strips, the increase in shear capacity of beam without stirrups (BNF-1) is $92.9 \%$ over that of control beam, while for beam with 150 $\mathrm{mm}$ stirrup spacing (BNF-3), the increase is only $18.7 \%$, while for similar beams made with high strength concrete the increase are 113.04\% (BHF-1) and $22.35 \%$ (BHF-3) respectively. Deniaud et al. [12] reported an increase of $40 \%$ and $21 \%$ for normal reinforced concrete beams strengthened with glass fiber 
with no stirrups and with $200 \mathrm{~mm}$ stirrups spacing respectively. Li et al. [11] concluded that the contribution of composite fabric to ultimate forces decreases as stirrups spacing reduced. In addition to that, Khalifa et al. [10] concluded that, the contribution of CFRP benefits the shear capacity at a greater degree for beams without shear reinforcement than for beams with adequate shear reinforcement. Moreover, Deniaud et al. [12] reported that the external FRP reinforcement can eventually reduce the shear capacity of the beam by changing the critical path that will lead to an even more sudden shear failure.

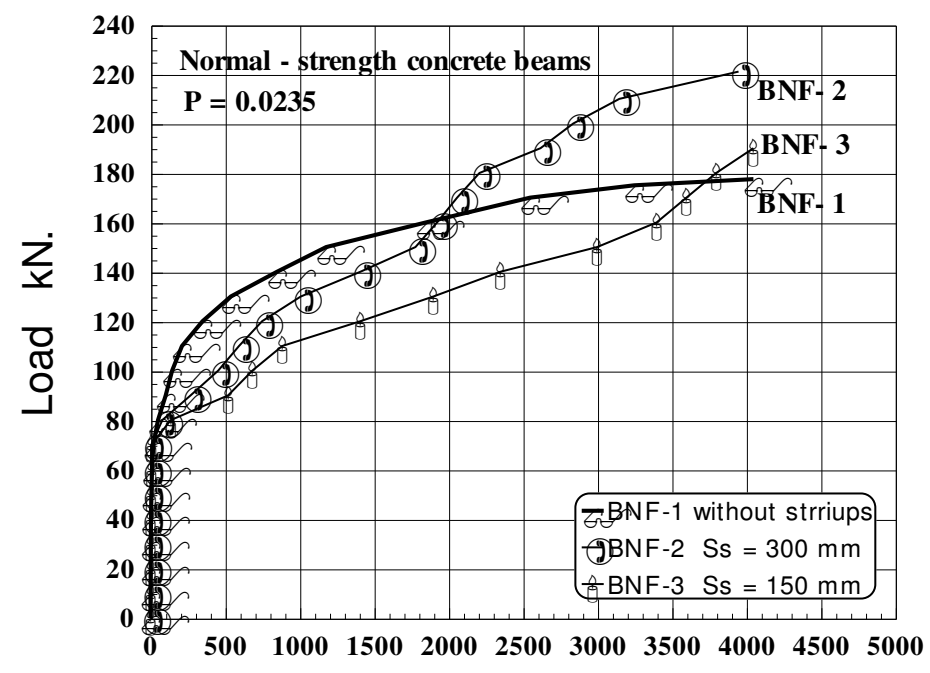

Fiber Strain

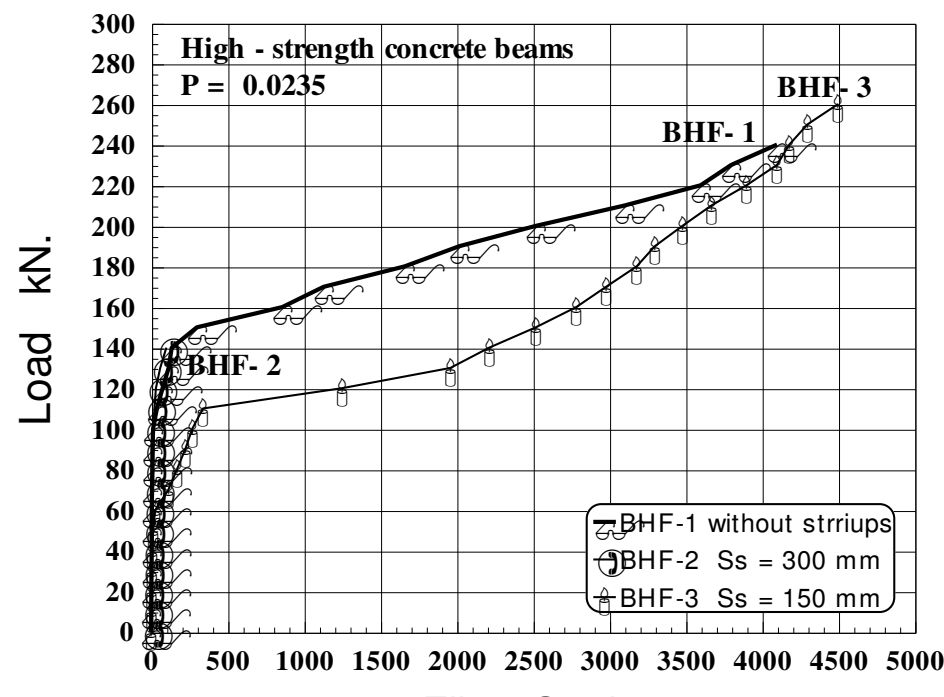

Fiber Strain

Fig.5: Load versus fiber strain (series 1 and 2) 


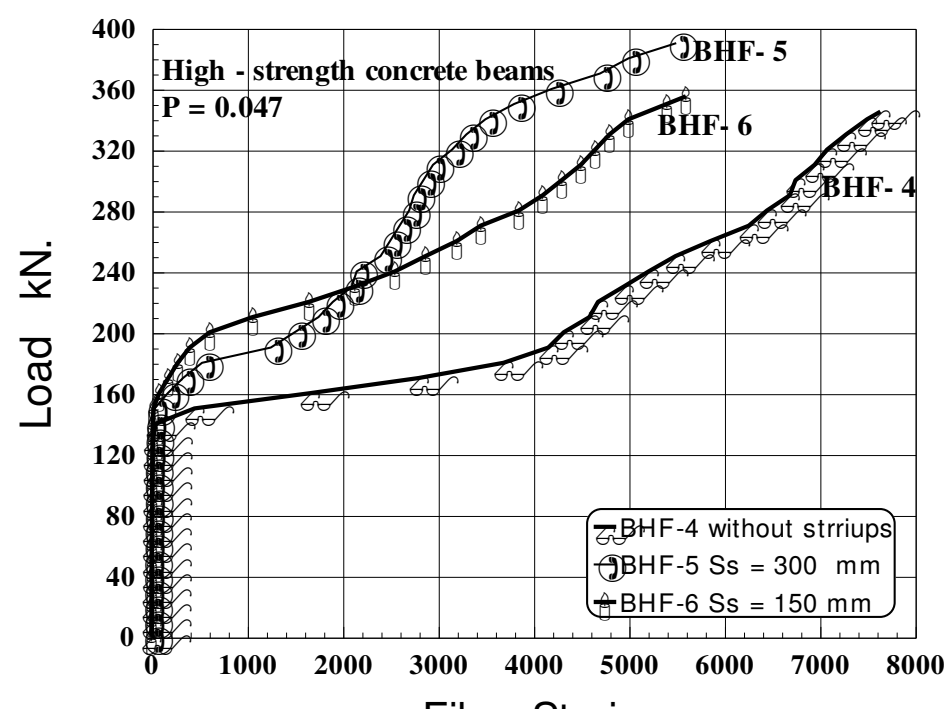

Fiber Strain

Fig.6: Load versus fiber strain (series 3)

\section{Influence of longitudinal steel ratio:}

Test results of beams in series 2 and 3 clarify that the contribution of composite fabric on the shear capacity of the strengthened beams varies according to longitudinal steel ratio. Increasing the amount of longitudinal steel ratio increased the net increase of the CFRP-U strips with respect to failure loadespecially in case of beams with no stirrups. A net increase of 113.04 and $138.9 \%$ was recorded in case of beams with no stirrups and having $\rho=0.0235$ and 0.047 respectively, (see Table 4). Li et al. [11] concluded that the contribution of composite fabric to ultimate forces decreases as the longitudinal steel bar section of a beam is reduced.

\section{Influence of concrete strength:}

Comparing results of beams in series 1 and 2 (Table 3) shows that the contribution of the CFRP-U strips to the shear capacity of the beam is dependent strongly on the compressive strength of concrete. The CFRP-U strips are less effective when the strengthened beams made from normal strength concrete, especially for those with no stirrups. For example the net increase in normal strength concrete beam BNF-1 is $92.9 \%$, while for beam BHF-1 made of high-strength concrete, the net increase is $113.0 \%$. 


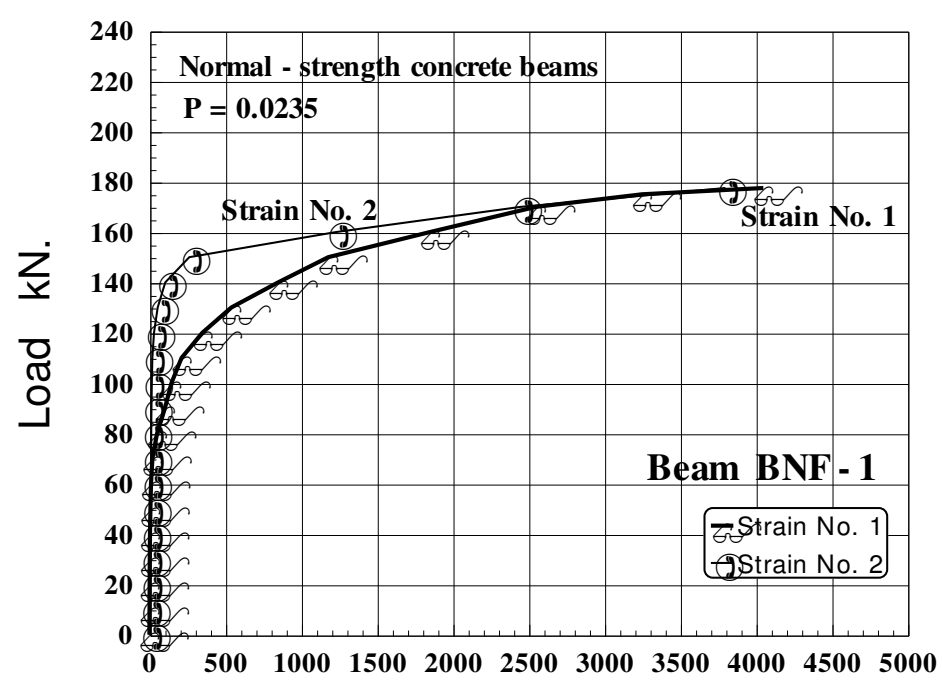

Fiber Strain

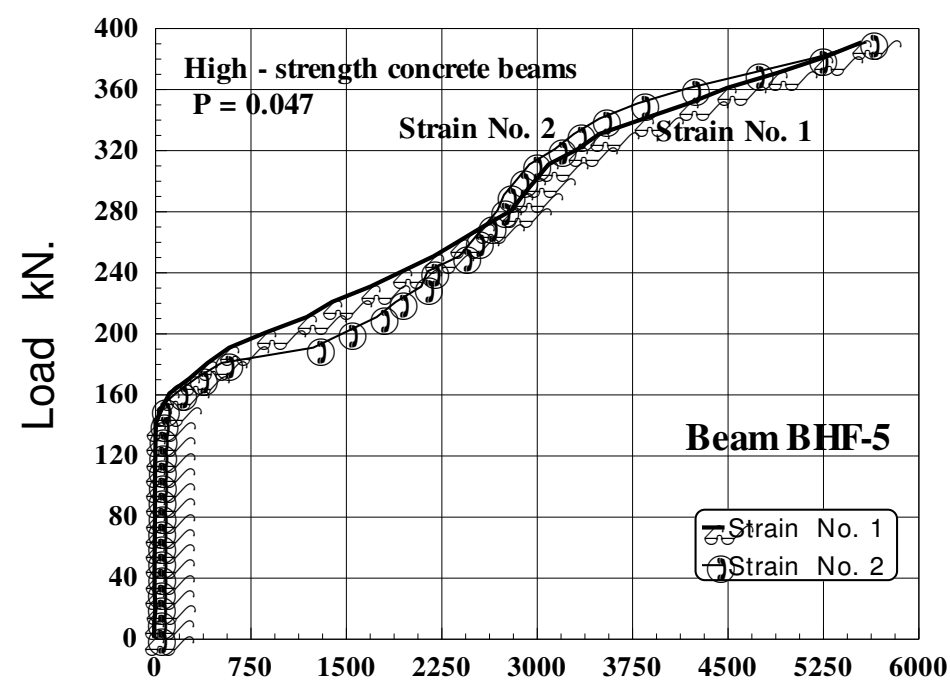

Fiber Strain

Fig.7: Load versus fiber strain for beams BNF-4 and BHF-5.

\section{ESTIMATION OF CONTRIBUTION OF CFRP TO SHEAR CAPACITY}

Many empirical models have been proposed to estimate the contribution of bonded FRP-U strips to the shear capacity of strengthened RC beams $[1,12,14$, 15, 16 and 19]. Among these models, the ACI code guidelines [14] and the 
recent published model by the author [1] were chosen to evaluate the shear capacity of the present strengthened beams. These two models can briefly presented as follows:

\section{ACl code equations [14]:}

$$
V_{f}=\phi \quad A_{f} f_{f e}\left(d_{f} / S_{f}\right)
$$

Where

$$
\begin{aligned}
& \mathrm{A}_{\mathrm{f}}=2 \mathrm{nt}_{\mathrm{f}} \mathrm{W}_{\mathrm{f}} \\
& \mathrm{f}_{\mathrm{fe}}=\varepsilon_{\mathrm{fe}} \mathrm{E}_{\mathrm{f}} \\
& \varepsilon_{\mathrm{fe}}=\mathrm{k}_{\mathrm{v}} \cdot \varepsilon_{\mathrm{fu}} \leq 0.04 \quad \text { (for U-wraps) } \\
& \mathrm{K}_{\mathrm{v}}=\mathrm{k}_{1} \mathrm{k}_{2} \mathrm{Le} / 11900 \varepsilon_{\mathrm{fu}} \leq 0.75 \\
& \mathrm{~L}_{\mathrm{e}}=23300 /\left(\mathrm{nt}_{\mathrm{f}} \mathrm{E}_{\mathrm{f}}\right)^{0.58} \\
& \mathrm{~K}_{1}=\left(\mathrm{f}_{\mathrm{c}}^{\prime} / 27\right)^{2 / 3} \\
& \mathrm{~K}_{2}=\left(\mathrm{d}_{\mathrm{f}}-\mathrm{L}_{\mathrm{e}}\right) / \mathrm{d}_{\mathrm{f}} \quad \text { (for U-wraps) }
\end{aligned}
$$

$\phi$ is the strength reduction factor $=0.85$

All length and force units are in mm and Newton.

In calculations, all code limitions are ignored, and all safety factors are taken equal to 1.0. It has to be mentioned that, the equations of the Egyptian code [19] are imilar to these mentioned above.

\section{Author's model [1]:}

$$
V_{f}=A_{f} \cdot f_{f e} \cdot\left(d_{f} / s_{f}\right)
$$

Where

$$
\begin{aligned}
& \mathrm{A}_{\mathrm{f}}=2 n \mathrm{t}_{\mathrm{f}} \mathrm{W}_{\mathrm{f}} \\
& \mathrm{f}_{\mathrm{fe}}=\mathrm{R} \cdot \mathrm{f}_{\mathrm{fu}} \\
& \mathrm{R}=\frac{0.4 \mathrm{k}^{2}\left(\mathrm{f}_{\mathrm{cu}}\right)^{2 / 3}}{\left(n E_{f} \mathrm{t}_{\mathrm{f}}\right)^{0.58} \varepsilon_{\mathrm{fu}}} \quad \leq 0.5
\end{aligned}
$$




$$
\begin{aligned}
& \mathrm{k}=\frac{d_{f}-\mathrm{L}_{\mathrm{e}}}{\mathrm{d}_{\mathrm{f}}} \\
& \mathrm{Le}=\sqrt{\frac{n E_{f} \cdot t_{f}}{\left(0.8 \mathrm{f}_{\mathrm{cu}}\right)^{0.5}}}
\end{aligned}
$$

All length and force units are in mm and Newton.

A comparison between the experimental values of $V_{\text {f.exp. }}$ to those derived from the above equations $V_{f . p r e}$ is given in Table (3). Results in this table showed that, ACI code equations, generally underestimated the contribution of CFRP-U strips to the shear capacity of beams with no stirrups and with stirrups of $300 \mathrm{~mm}$ spacing, while overestimated those with stirrups of $150 \mathrm{~mm}$ spacing. This is in agreement with the observations reported by others $[1,4$ and 10]. However, the equations of the author model [1] estimated properly the contribution of the U-strips for beams in series 1 and 2, with no stirrups or and stirrups of $300 \mathrm{~mm}$ spacing, but overestimated those with stirrups of 150 $\mathrm{mm}$ spacing in all series This may be due to the fact that, the influence of both transverse and longitudinal steel reinforcement and a/d ratio on the contribution of FRP-strips to the shear capacities is not reflected in the equations of ACI code and author's model, although this influence is clearly demonstrated by the present tests and those carried out by others [4,10 and 12]. In addition to that, the equations of author's model are based on experimental results of members made of normal strength concrete. Therefore a trial, using statistical analysis of the experimental results of the tested specimens, has been made to modify the equations of the author model to take into account the influence of the above parameters. This modification is done in the value of effective stress, $\mathrm{f}_{\mathrm{fe}}$, because this is the only unknown in equation (9) to be determine for completing the analysis of CFRP contribution to shear capacity, as follows:

$$
\mathrm{f}_{\mathrm{fe}}=\mathrm{R}\left[1+\left(\rho \frac{\mathrm{d}}{\mathrm{a}}\right)^{1 / 3}\right]\left[\frac{\mathrm{S}_{\mathrm{S}}}{\mathrm{d}}\right]^{1.6}, \quad \mathrm{~S}_{\mathrm{s}} / \mathrm{d} \leq 1.0
$$

Where:

$$
\mathrm{R}=\frac{0.4 \mathrm{k}^{2}\left(\mathrm{f}_{\mathrm{cu}}\right)^{2 / 3}}{\left(n E_{f} \mathrm{t}_{\mathrm{f}}\right)^{0.58} \varepsilon_{\mathrm{fu}}} \leq 0.5
$$

$\mathrm{K}, \mathrm{L}_{\mathrm{e}}$ and $\mathrm{V}_{\mathrm{f}}$ as given above in equations of the author model. 
Table 3: Comparison between experimental and analytical results

\begin{tabular}{|c|c|c|c|c|c|c|c|c|}
\hline \multirow[b]{2}{*}{$\begin{array}{l}\text { Resea- } \\
\text { rcher }\end{array}$} & \multirow{2}{*}{$\begin{array}{c}\text { Beam } \\
\text { No. }\end{array}$} & \multirow{2}{*}{$\begin{array}{c}\text { Failure } \\
\text { load } \\
(\mathrm{KN}) \\
\end{array}$} & \multirow[b]{2}{*}{$\begin{array}{c}\mathcal{E}_{\text {f.max. }} \\
(\%)\end{array}$} & \multirow{2}{*}{$\begin{array}{l}V_{\text {f.exp. }} \\
(\mathrm{KN})\end{array}$} & \multicolumn{3}{|c|}{$V_{\text {f.pre. }}(K N)$} & \multirow{2}{*}{$\begin{array}{l}\text { Failure } \\
\text { mode }\end{array}$} \\
\hline & & & & & $\begin{array}{c}\mathrm{ACl} \\
\text { code[14] }\end{array}$ & $\begin{array}{l}\text { Author } \\
\text { model[1] }\end{array}$ & $\begin{array}{l}\text { Modf. } \\
\text { Eqns. }\end{array}$ & \\
\hline \multirow{18}{*}{ 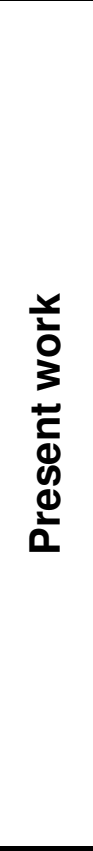 } & $\mathrm{BN}-1$ & 92.0 & - & - & - & - & - & Shear \\
\hline & BNF-1 & 177.5 & 0.405 & 42.75 & 25.93 & 37.42 & 45.14 & Shear \\
\hline & $\mathrm{BN}-2$ & 122.0 & - & - & - & - & - & Shear \\
\hline & BNF-2 & 221.0 & 0.392 & 49.5 & 25.37 & 36.47 & 44.0 & Shear \\
\hline & $\mathrm{BN}-3$ & 160.5 & - & - & - & - & - & Shear \\
\hline & BNF-3 & 190.5 & 0.400 & 15.0 & 24.80 & 35.49 & 16.72 & Shear \\
\hline & $\mathrm{BH}-1$ & 115.0 & - & - & - & - & - & Shear \\
\hline & BHF-1 & 245.0 & 0.410 & 65.0 & 45.96 & 59.04 & 71.23 & Shear \\
\hline & $\mathrm{BH}-2$ & 183.0 & - & - & - & - & - & Shear \\
\hline & BHF-2 & 252.5 & 0.010 & 34.75 & 45.22 & 59.04 & 71.23 & Flexure \\
\hline & $\mathrm{BH}-3$ & 212.5 & - & - & - & - & - & Shear \\
\hline & BHF-3 & 260.0 & 0.455 & 23.75 & 44.58 & 59.04 & 27.82 & Flexure \\
\hline & $\mathrm{BH}-4$ & 144.0 & - & - & - & - & - & Shear \\
\hline & BHF-4 & 344.0 & 0.764 & 100.0 & 46.42 & 59.04 & 74.39 & Shear \\
\hline & $\mathrm{BH}-5$ & 205.0 & - & - & - & - & - & Shear \\
\hline & BHF-5 & 390.0 & 0.550 & 92.5 & 45.96 & 59.04 & 74.39 & Shear \\
\hline & BH-6 & 265.0 & - & - & - & - & - & Shear \\
\hline & BHF-6 & 358.0 & 0.560 & 46.5 & 45.035 & 59.04 & 29.1 & Shear \\
\hline \multirow{2}{*}{$\Xi \Xi$} & PU-1 & - & - & 32.5 & 29.53 & 42.31 & 30.3 & Shear \\
\hline & PU-2 & - & - & 20.0 & 23.62 & 33.84 & 24.27 & Shear \\
\hline \multirow{3}{*}{ 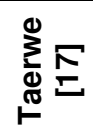 } & PS-2 & - & - & 41.2 & 24.18 & 36.93 & 44.17 & Shear \\
\hline & BS-5 & - & - & 33.4 & 12.52 & 18.46 & 22.10 & Shear \\
\hline & PS-6 & - & - & 30.0 & 8.18 & 11.20 & 14.72 & Shear \\
\hline
\end{tabular}

Table (3) and Fig. (8) show a comparison between the computed values of $\mathrm{V}_{\text {f.pre. }}$ using the above modification and the experimental $\mathrm{V}_{\text {f.exp. }}$ values for strengthened beams collected from present research and these conducted by others [11 and 17] in comparison with those calculate using ACI code [14]. The comparison indicates that the modified equations, gives acceptable accuracy and sometimes conservative, while ACI code equations failed to capture the influence of the studied parameters. It has to be mentioned that, due to the complex interaction exists between concrete, internal steel reinforcement, and CFRP shear reinforcement, as indicated by the results of the present research and those conducted by others [4,10 and 12], it is difficult to predict the contribution of the CFRP strips to the shear capacity of beams accurately until more experiments are available. 


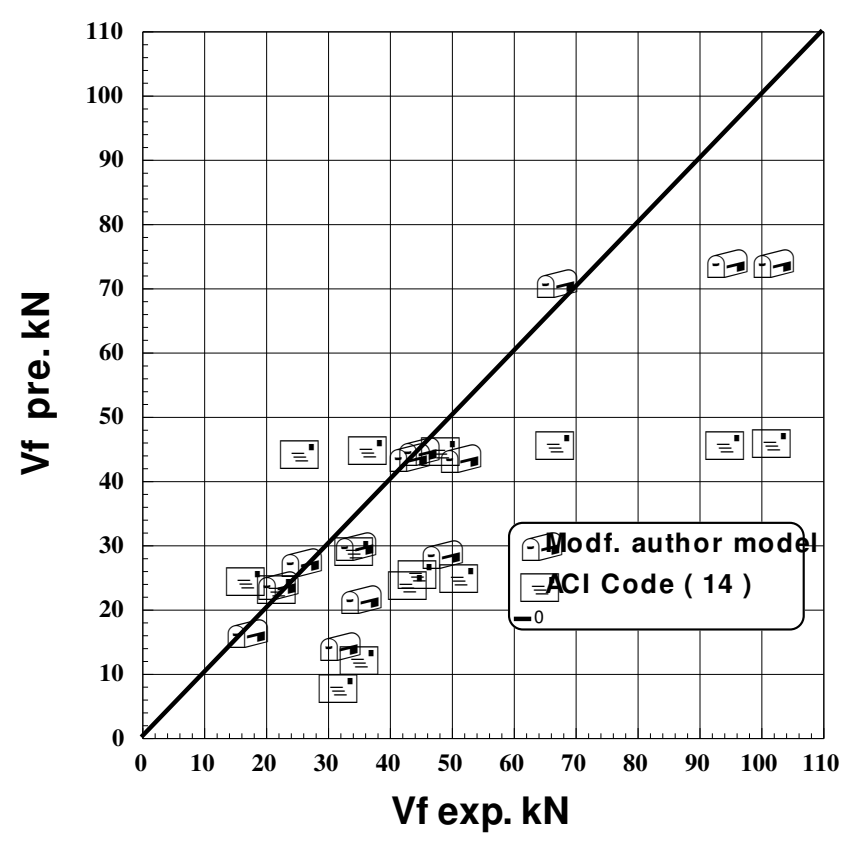

Fig.8: Comparison between experimental and predicted values of $V_{f}$.

\section{CONCLUSIONS}

Based on the analysis and discussion of the experimental and analytical results given above, the following conclusions can be drawn:

1. The contribution of the CFRP-U strips to the shear capacity of RC beams depends not only on the dimensions and spacing of strips [1] but also on the amount of internal shear reinforcement (stirrups), amount of longitudinal steel reinforcement, and concrete compressive strength.

- The gain in shear capacity increases as the amount of internal shear reinforcement decreases, i.e. CFRP strips are less effective when beams are heavily reinforced with internal shear reinforcement.

- Increasing amount of longitudinal steel increased the net increase in ultimate shear load, specially for beams without stirrups.

- As the compressive strength of concrete increased, the CFRP strips contribution to the shear capacity increased.

2. Failure of strengthened beams were more sudden and explosive as concrete strength and/or amount of longitudinal reinforcement increased, especially for beams without stirrups.

3. The maximum CFRP strains measured just before failure were higher in specimens made of high strength concrete compared to those made of normal strength concrete, and also increased as amount of longitudinal steel increased.

4. The CFRP strains are uniformly distributed among the strips crossing the 
path of the concrete shear crack.

5. Comparison between experimental and calculated values of $\mathrm{V}_{\mathrm{f}}$ indicates that the modified equations, developed to predict the contribution of CFRP-U strips to the shear capacity of RC beam, gives acceptable and sometimes conservative estimates, while the guidelines of ACI code fail to capture the influence of the studied parameters.

\section{Recommendations for Future Work:}

- Interaction between the contribution of external CFRP and internal shear reinforcement (stirrups) still needs to be investigated. This investigation has to consider the following parameters: main steel ratio, a/d ratio, concrete strength, type of fibers, and scale effect.

- The proposed equations needs to be expanded to include the effect of the above parameters to enhances its accuracy.

\section{REFERENCES}

1. Abd El-Hafez, A.M. "Shear Behaviour of RC Beams Strengthened Externally with Bonded CFRP-U Strips", J.ES, Journal of Engineering Science, University of Assiut, Vol. 35 No. 2, March 2007.

2. Barros, J.A.O., Dias, S.J.E., and Lima, J.L.T. "Efficacy of CFRP-based Techniques for the Flexural and Shear Strengthening of Concrete Beams", Cement and Concrete Composites, Vol. 29, Issue 3, March 2007, pp. 203217.

3. Monti, G., and Liotta, M.A. "Tests and Design Equations for FRPStrengthening in Shear", Construction and Building Materials, Vol. 21, Issue 4, April 2007, pp. 799-809.

4. Boussiham, A., and Chaallah, O. "Effect of Transverse Steel and Shear Span on the Performance of RC Beams Strengthened in Shear With CFRP", Composites Part B: Engineering, Vol. 37, Issue 1, Jan-2006, pp. 37-46.

5. Barros, J.A.O., and Dias, S.J.E., "Near Surface Mounted CFRP Laminates for shear Strengthening of Concrete Beams", Cement and Concrete composites, Vol. 28, Issue 3, March 2006, pp. 276-292.

6. Chen, J.F., and Teng, J.G., "Shear Capacity of FRP-Strengthened RC Beams: FRP Debonding". Construction and Building Materials, Vol. 17, Issue 1, Feb. 2003, pp. 27-41.

7. Taljsten, B., "Strengthening Concrete Beams for Shear with CFRPSheets", Construction and Building Materials, Vol. 17, Issue 1, Feb. 2003, pp. 15-26.

8. Diagana, C., Li, A., and Delmas, Y., "Shear Strengthening Effectiveness with CFF, Strips", Engineering Structures, Vol. 25, Issue 4, March 2003, pp. 507-516. 
9. Teng, J.G.; Chen, J.F.; and Smith, S.T., "FRP Strengthened RC Structures" John Wiley and Sons Ltd., West Sussex, England, 2002.

10. Khalifa, A., and Nanni, A., "Rehabilitation of Rectangular Simply Supported RC Beams with Shear Deficiencies Using CFRP Composites", Construction and Building Materials, Vol. 16, Issue 3, April 2002, pp. 135-146.

11. Li, A., Diagana, C., and Delmas, Y., "Shear Strengthening Effect of Bonded Composite Fabrics on RC Beams", Composites Part B: Engineering, Vol. 33, Issue 3, April 2002, pp. 225-239.

12. Deniaud, C.; and Cheng, J.J.R., "Shear Behaviour of Reinforced Concrete T-Beams with Externally Bonded Fiber-Reinforced Polymer Sheets", ACI Structural Journal, Vol. 98, No. 3, May-June 2001, pp. 386396.

13. Triantafillou, T.C., "Shear Strengthening of Reinforced Concrete Beams Using Epoxy-Bonded FRP composites", ACI Structural Journal, Vol. 95, No. 2, March-April 1998, pp. 107-115.

14. ACI 440.2R-02, "Guide for the Design and Construction of Externally Bonded FRP Systems for Strengthening Concrete Structures", Farmington Hills, Michigan, American Concrete Institute 2002; 45 [From Ref. 5].

15. Ye, L.P.; Lu, X.Z.; and Chen, J.F., "Design Proposals for the Debonding Strengths of FRP Strengthened RC Beams in the Chinese Design Code", Proc. Of International Symposium on bond Behaviour of FRP in Structures, Hong Kong-China, Dec. 2005, pp. 95 - 54.

16. Deniaud, C.; and Chen, J.J.R., "Simplified Shear Design Method for Concrete Beams Strengthened with Fiber Reinforced Polymer Sheets", Journal of Composites for Construction, ASCE, Sept.-Oct., 2004, pp. 425 -433 .

17. Taerwe, L., Khalil, H., and Mathys, S., "Behaviour of RC Beams Strengthened in Shear by External CFRP Sheets", Proc. Of the III Inter. Symp. Non Metallic (FRP) Reinforcement. For Concrete Structures, Japan, 1997, pp. 983-490 (From Ref. 18).

18. Aprile, A., and Benedetti, A., "Coupled Flexural-Shear Design of RC Beams Strengthened with FRP", Composites Part B: Engineering, Vol. 35, Issue 1, Jan. 2004, pp. 1-25.

$$
\begin{aligned}
& \text { مسودة الكود المصري لأسس تصميم واشتراطات تتفيذ البوليمرات المسلحة بالألياف في مجالات } \\
& \text { التشييد ، يوليو } 2005 \text {. }
\end{aligned}
$$


تأثير الكانات ومقاومة الخرسانة على سلوك الكمرات الخرسانية المقواة خارجياً في منطقة القص بشرائح نسيج ألياف الكريون

إن تقنيـة اسـتخدام بـوليمرات ألبـاف الكربـون المقوى (CFRP) في عمليـة تـدعيم وإصـلاح عناصـر المنشآت الخرسانية أصبحت شائعة لما لهذه الألياف من مميزات كثيرة بجانب سهولة تلفيذهاتها عمليًا. وطبقاً للمعلومات المتاحة، فإن العديد من المتغيرات التي تؤثز على سلوك الكمرات الخرسانية المقواه

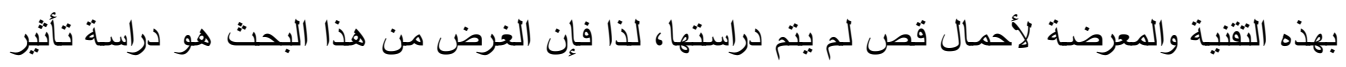

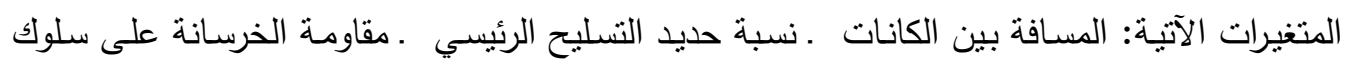

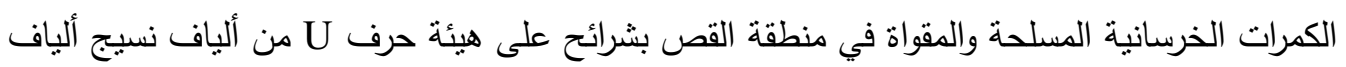
• الكربون

وقد شملت الدراسة تأثثر تلك المتغيرات على شكل الثروخ وأنماط الانهيار قيم الترخيم ـالانفعال

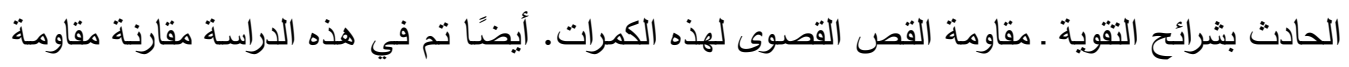
القص القصوى التي تساهم بها الألياف والتي تم الحصول عليها معمليًا لهذه الكمرات بتلك المحسوبة فئل

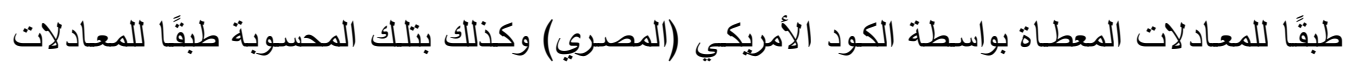

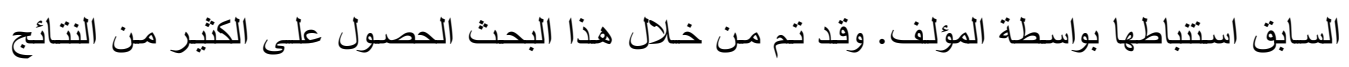
المعلية التي تقيد الباحثين والقائمين بعمليات تدعيم المنشآت الخرسانية. نذكر من تلأك النتائج:

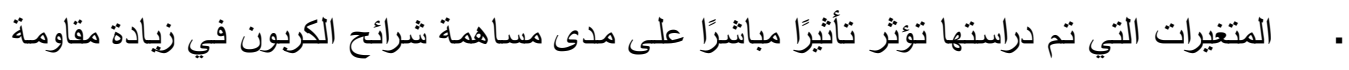

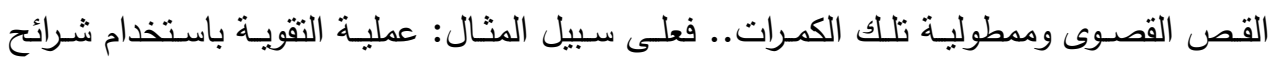

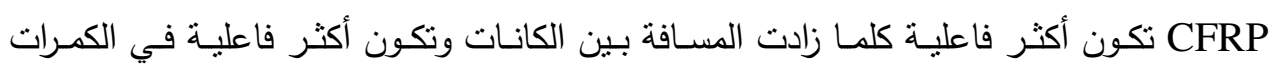

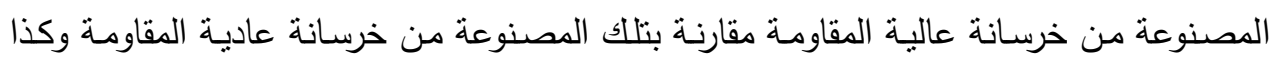
تزداد هذه الفاعلية بزيادة نسبة حديد النسليح الرئيسي.

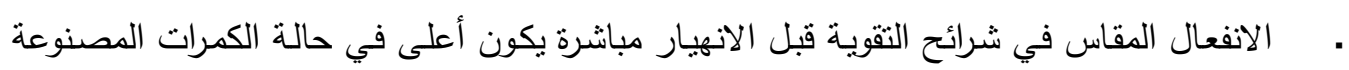

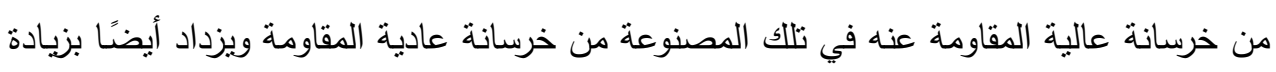

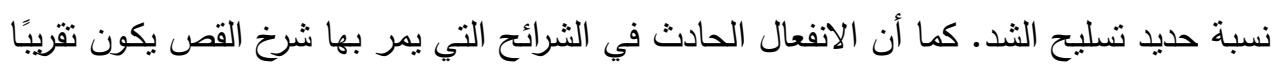

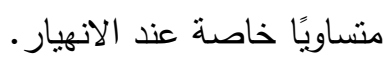
• معادلات الكود الأمريكي (المصري) فثلت في التتبؤ بالقيم التي تساهم بها شرائح التقوية في مقاومة

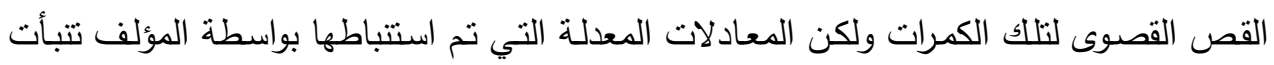
بهذه المساهمة بطريقة مقبولة. 
في نهاية البحث نم تدوين المتغيرات التي يجب أن تدرس مستقبلا لزيادة فهم هذه السلوك والتأكد من دقة نتائج المعادلات المسنتبطة. 